\title{
Partial practical stability for fractional-order nonlinear systems
}

\author{
Abdellatif Ben Makhlouf ${ }^{1}$ \\ ${ }^{1}$ Al-Jouf University College of Science
}

May 5, 2020

\begin{abstract}
In this paper, using the Lyapunov-like functions, the practical stability with respect to part of the variables of fractional-order nonlinear systems depending on a small parameter is studied.
\end{abstract}

\section{Hosted file}

Paper.pdf available at https://authorea.com/users/302432/articles/432519-partial-practicalstability-for-fractional-order-nonlinear-systems 